\title{
Genetic Resistance in Melon PI 313970 to Cucurbit yellow stunting disorder virus
}

\author{
James D. McCreight ${ }^{1}$ and William M. Wintermantel \\ U.S. Department of Agriculture, Agricultural Research Service, U.S. \\ Agricultural Research Station, 1636 E. Alisal Street, Salinas, CA 93905 \\ Additional index words. Cucumis melo, sweet potato whitefly, Bemisia tabaci
}

\begin{abstract}
Melon (Cucumis melo L.) is a fresh vegetable and dessert fruit that may also be cooked or dried, processed for juice and flavoring, and the seeds of which are a source of high-quality cooking oil and high protein seed meal. Melon production throughout many parts of the world is now threatened by the crinivirus Cucurbit yellow stunting disorder virus (CYSDV) in tropical and subtropical areas favorable to its whitefly vector. CYSDV is transmitted by the sweetpotato whitefly, Bemisia tabaci Gennadius, biotypes A, B, and Q. CYSDV first appeared on melon in the 1980s in the United Arab Emirates and emerged on melon in the Yuma, AZ, and Imperial Valley, $\mathrm{CA}$, regions and western Mexico during the Fall season of 2006 followed by Florida in 2007. PI 313970, C. melo var. acidulus Naudin, a salad-type melon from India, expressed high-level resistance to CYSDV in Yuma and Imperial Valley in Fall 2006, but it was not immune; the virus was detected in asymptomatic plants. Inheritance of resistance to CYSDV in PI 313970 was studied in three naturally infected, replicated field tests in Imperial Valley during the Fall seasons of 2007 and 2008 and the Spring season of 2009. Resistance in PI 313970 was recessive: all $F_{1}$ PI 313970 (PI) $\times$ susceptible 'Top Mark' $(T M)$ and $B C_{T M}$ individuals were susceptible, and the $F_{2}$ and $B C_{P I}$ segregated 3:1 and 1:1 susceptible to resistance, respectively. Frequency distributions of CYSDV symptom severity ratings suggested a single recessive gene in PI 313970 for resistance to CYSDV. PI 313970 was, however, observed to be variable for resistance; a few plants in each test expressed distinct symptoms of CYSDV infection and its frequency distributions overlapped those of 'Top Mark'. This variation may represent genetic variation selectable for uniform reaction to infection by CYSDV or phenotypic variation in the resistant reaction. The genetic relationship between the genes for resistance to CYSDV in PI 313970 (recessive) and TGR-1551 (dominant) is not known.
\end{abstract}

Melon (Cucumis melo L.) is a fresh vegetable and dessert fruit that may also be cooked, dried, or processed for juice and flavoring. Melon seeds may be roasted and eaten like nuts and are a source of highquality cooking oil and high-protein seed meal (McCreight et al., 1993). The world production of melons in 2009 was estimated at 25.5 million MT from 1.09 million ha of land, which was a $40 \%$ increase in production from 14\% more land than in 1999 (FAO, 2011). The United States and Mexico account for $\approx 5 \%$ of the world production of melons (Dhillon et al., 2011). Arizona and California

\footnotetext{
Received for publication 25 Aug. 2011. Accepted for publication 31 Oct. 2011.

Funded in part by a grant from the California Melon Research Board.

We thank Patti Fashing for assistance in the field tests and Art Cortez, Mario Estrada, Laura Hladky, and Ruby Renteria for assistance in laboratory assays. USDA is an equal opportunity provider and employer. Mention of trade names or commercial products in this publication is solely for the purpose of providing specific information and does not imply recommendation or endorsement by the U.S. Department of Agriculture.

${ }^{1}$ To whom reprint requests should be addressed; e-mail jim.mccreight@ars.usda.gov.
}

are the major producers of cantaloupe and honeydew melons in the United States. These states accounted for $80 \%$ of the area planted to cantaloupe (30,809 ha) and $96 \%$ of the area planted to honeydew $(6,799$ ha) in 2009 . They produced $84 \%$ and $94 \%$ of the yields and $78 \%$ and $93 \%$ of the value of cantaloupe $(\$ 359.1 \mathrm{M})$ and honeydew (\$59.1 M) melons, respectively, in the United States (USDANASS, 2010).

Cucurbit yellow stunting disorder virus (CYSDV; family Closteroviridae, genus Crinivirus) was first recognized on melon in the 1980s in the United Arab Emirates (Hassan and Duffus, 1990) and is a threat to melon production worldwide. It has been reported in China (Liu et al., 2010), Cyprus (Papayiannis et al., 2005), Egypt (Duffus, 1995; Eid et al., 2006), France (Desbiez et al., 2003), Greece (Elena et al., 2008; Papayiannis et al., 2005), Guatemala (R.J. Gilbertson, personal communication), Iran (Keshavarz and Izadpanah, 2004), Israel (Berdiales et al., 1999; Duffus, 1995), Jordan (Rubio et al., 1999), Lebanon (Abou-Jawdah et al., 2000), Mexico (Brown et al., 2007), Morocco (Desbiez et al., 2000), Portugal (Louro et al., 2000), Saudia Arabia (Rubio et al., 1999), Spain (Berdiales et al., 1999), Syria (Duffus, 1995), Tunisia (Yakoubi et al., 2007), and Turkey (Rubio et al., 1999).
In the United States, it has been identified in Arizona, California, Florida, and Texas (Kao et al., 2000; Kuo et al., 2007; Polston et al., 2008).

CYSDV can infect members of seven plant families, all of which are found in the desert southwestern of the United States, that include 12 non-cucurbit host plants (Wintermantel et al., 2009). The host range of CYSDV is similar in size to that of other members of the genus Crinivirus such as Beet pseudo-yellows virus, which infects an exceptionally broad array of hosts including members of 12 taxonomic families (Duffus, 1965; Tzanetakis et al., 2003; Wintermantel, 2004).

Sweet potato whitefly, Bemisia tabaci (Gennadius), biotype B (SPWF-B) adversely affects yield and quality of a wide range of vegetable and agronomic crops worldwide directly through feeding damage or indirectly as a virus vector (Henneberry et al., 1998). It is known to transmit 111 virus species including CYSDV (Jones, 2003). Together, SPWF-B and CYSDV threaten to eliminate fall season melon production in the Sonoran Desert areas of the southwestern United States (Arizona and California) and western Mexico where CYSDV emerged in 2006 (Brown et al., 2007; Kuo et al., 2007). The CYSDV epidemic has recurred annually since the initial outbreak in these regions, and CYSDV and its vector appear to be firmly established in the region.

The 2006 outbreak of CYSDV resulted in an estimated $\$ 14 \mathrm{M}$ loss in Arizona melon production alone (J.C. Palumbo, Univ. Arizona, personal communication). Mean cantaloupe and honeydew yields of the spring and fall crops in Arizona dropped from 5.8 MT per ha in 2007 to 4.1 MT per ha in 2009 (USDANASS, 2009). This $30 \%$ reduction in yield of cantaloupe and honeydew was based on the total production of the spring and fall seasons and thus underestimates the actual reduction in the fall crop where some fields suffered complete crop loss. Fall season cantaloupe and honeydew in Arizona was reduced by $76 \%$ from pre-2006 levels after correction for differences in hectares of melons planted in the two seasons and assuming constant (i.e., the same as in 2007) yield in the spring crop where SPWF-B pressure and infection by CYSDV as well as incidence of aphid-borne viruses have been very low. Fall melon production in Imperial Valley, CA, is radically different from that in 2005, the last season before the emergence of CYSDV: less than 80 ha of cantaloupe in 2009 vs. 283 ha in 2005 (Birdsall, 2007). The situation is especially stark in contrast to Fall 1989, the year before the appearance of SPWF-B, when there were 4990 ha of cantaloupe and honeydew in Imperial County (Birdsall, 1991). These serious losses to growers in a period of reduced management options are directly attributable to the adverse impacts of SPWF-B feeding and CYSDV infection.

Host plant resistance to CYSDV was first observed in melon accession TGR-1551 (PI 482420; subsp. melo), a salad-type melon from Zimbabwe. TGR-1551 expressed high-level, 
monogenic dominant resistance to a Spanish strain of CYSDV (López-Sesé and GómezGuillamón, 2000), but when challenged with a Texas strain of CYSDV, it expressed intermediate resistance and the $\mathrm{F}_{2}$ segregation data did not fit a mono- or digenic, dominant gene model (Sinclair, 2003).

Reactions of 19 melon cultigens (cultivars, breeding lines, and PIs) to CYSDV in Imperial Valley, CA, and Yuma, AZ, in Fall 2006 confirmed a previous report (López-Sesé and Gómez-Guillamón, 2000) of susceptible reactions of several of these cultigens to CYSDV inoculation but revealed a new putative source of genetic resistance to CYSDV: PI 313970 , var. acidulus Naudin, a salad-type melon from India (McCreight and Wintermantel, 2008). PI 313970 was previously reported resistant to SPWF-B (Boissot et al., 2003).

We report the inheritance of host plant resistance in PI 313970 to CYSDV in the Fall seasons of 2006 and 2007 and the Spring season of 2009. The three studies were carried out in naturally infected field plantings at the University of California, Desert Research and Education Center (DREC), Holtville, $\mathrm{CA}$. The fall season in Imperial Valley typically has high SPWF-B feeding pressure in contrast to low pressure in the spring season (McCreight et al., 2010).

\section{Materials and Methods}

PI 313970 (PI) was crossed with 'Top Mark' (TM; var. reticulatus), a western U.S., shipping-type, orange-fleshed muskmelon. Seed of the parents, $F_{1}, F_{2}$, and respective backcross generations were made from controlled self- and sib-pollinations in a greenhouse at Salinas, CA (McCreight et al., 1992; Robinson and Decker-Walters, 1997). Different progenies of each generation were used in the three tests. 'Top Mark' was obtained from a commercial source.

The plants in all three tests were grown using standard commercial practices with irrigation provided as needed by subsurface drip (20-cm depth). Admire ${ }^{\circledR}$ (imidacloprid) was applied once at the label rate through the drip $5 \mathrm{~d}$ after the initial irrigation. Bed width $(2.0 \mathrm{~m})$ and number of seed per plot (five) were consistent through the three tests, but plot length, seed spacing, numbers of entries, and replications varied among the tests. Plants were individually evaluated for foliar symptoms of CYSDV using a different rating scale in each test (Table 1). The CYSDV data were subjected to analysis of variance and protected means separations (Student's $t$ test) using JMP 8.0.1 (SAS Institute, Cary, NC).

Experimental plots in the Fall 2007 and 2008 tests were $9.1 \mathrm{~m}$ long and seed were planted $1.5 \mathrm{~m}$ apart. Each of the seven replications in the 2007 test included one plot of each parent and $F_{1}$ PI $313970 \times$ 'Top Mark', five plots of one $\mathrm{F}_{2}$ progeny, and two plots of each backcross $\left(\mathrm{BC}_{\mathrm{TM}}\right.$ and $\left.\mathrm{BC}_{\mathrm{PI}}\right)$. The 2007 test was planted on 5 Sept. and evaluated 49 and $74 \mathrm{~d}$ post-planting (dpp) on 24 Oct. and 18 Nov., respectively. CYSDV

Table 1. Rating scales used for evaluation of foliar symptoms of Cucurbit yellow stunting disorder virus in naturally infected field tests in 2007, 2008, and 2009, Holtville, CA. ${ }^{2}$

\begin{tabular}{|c|c|c|c|c|c|}
\hline \multicolumn{2}{|r|}{2007} & \multicolumn{2}{|r|}{2008} & \multicolumn{2}{|r|}{2009} \\
\hline \multirow[t]{2}{*}{$\overline{1}$} & Asymptomatic & 1 & Asymptomatic & 1 & $\leq 10 \%$ \\
\hline & & 2 & Possible & 2 & $11 \%$ to $20 \%$ \\
\hline \multirow[t]{2}{*}{2} & Mild & 3 & Faint at crown & 3 & $21 \%$ to $30 \%$ \\
\hline & & 4 & Obvious at crown & 4 & $31 \%$ to $40 \%$ \\
\hline \multirow[t]{5}{*}{3} & Restricted to crown leaves & 5 & Bright at crown & 5 & $41 \%$ to $50 \%$ \\
\hline & & 6 & Advancing toward tips & 6 & $51 \%$ to $60 \%$ \\
\hline & & 7 & Advancing toward tips, bright & 7 & $61 \%$ to $70 \%$ \\
\hline & & 8 & Some tips symptomatic & 8 & $71 \%$ to $80 \%$ \\
\hline & & & & 9 & $81 \%$ to $90 \%$ \\
\hline 4 & Extensive from crown to tips & 9 & All tips symptomatic & 10 & $91 \%$ to $100 \%$ \\
\hline
\end{tabular}

${ }^{\text {zThe }} 2007$ and 2008 scales characterized symptom expression; their approximate equivalence is indicated by their vertical placement within the table. The semiquantitative scale used in 2009 estimated the percentage of foliage that expressed symptoms without regard to symptom characteristics.

symptoms were evaluated using a 1 to 4 scale (Table 1). The 2008 test was similar with the exception that reciprocal $\mathrm{F}_{1}$ progenies were included. The test was planted on 1 Oct. and evaluated 50 and $63 \mathrm{dpp}$ on 20 Nov. and 3 Dec., respectively. CYSDV symptoms were evaluated using a 1 to 9 scale (Table 1 ).

In the Spring 2009 test, experimental plots were $12.1 \mathrm{~m}$ long and seeds were planted 1.8 $\mathrm{m}$ apart. Each of the six replications included one plot of each parent, the $\mathrm{F}_{1}$ progeny and $\mathrm{BC}_{\mathrm{TM}}$, five plots of one $\mathrm{F}_{2}$ progeny, and three plots of $\mathrm{BC}_{\mathrm{PI}}$. The test was planted on $2 \mathrm{Apr}$. and evaluated $82 \mathrm{dpp}$ on 23 June CYSDV symptoms were evaluated using a 1 to 10 scale (Table 1).

Plants were also individually examined for foliar symptoms of two other diseases that may occur on melon in the spring and fall seasons in Imperial Valley: Cucurbit leaf crumple virus $(\mathrm{CuLCrV}$; Geminiviridae, Begomovirus) in the fall (Guzman et al., 2000) and Podosphaera xanthii (Castagne) Braun \& Shishkoff, a causal agent of melon powdery mildew (McCreight, 2006) in the spring and fall. Observation of symptoms of other pathogens present in the field was necessary to determine if these might influence evaluation of CYSDV resistance. CuLCrV was noted as present or absent. Powdery mildew was evaluated using a 1 to 9 scale previously described and resistant blisters were noted as present or absent (McCreight, 2006; Sedlářová et al., 2009).

Correlation of CYSDV infection with the presence of CYSDV-like symptoms was confirmed in 2007 at the time of symptom evaluation with reverse transcription-polymerase chain reaction (RT-PCR) and nucleic acid hybridization using major coat protein and HSP70 gene-specific probes and primers (Kuo et al., 2007). Each diagnostic sample consisted of a single $0.1-\mathrm{g}$ piece from the interveinal area of a leaf on the main stem or one of the first lateral branches that exhibited early-to-moderate CYSDV symptoms. Presence of $\mathrm{CuLCrV}$ was confirmed visually based on symptoms. Symptoms of CuLCrV infection are distinct from those of CYSDV, can appear by $10 \mathrm{dpp}$, and are most evident at the terminal buds, whereas symptoms of CYSDV infection appear in expanded crown leaves and develop acropetally (McCreight et al., 2008).

\section{Results}

SPWF feeding pressure, as a function of the numbers of SPWF-B adults per leaf and eggs + nymphs $/ \mathrm{cm}^{2}$, was similar in the 2007 and 2008 tests (Fall seasons) but was lower in the 2009 (Spring season) test (McCreight et al., 2010). The heavy SPWF-B pressure in the fall season appeared to suppress expression of CYSDV symptoms yet adversely affect plant growth in contrast to lower SPWF-B pressure in spring where CYSDV symptom expression and plant growth were inversely correlated for 'Top Mark' and PI 313970 (McCreight et al., 2010). CYSDV infection was uniform across each test regardless of SPWF population level as indicated by uniform expression of CYSDV symptoms in the test and surrounding border rows and guard plots (data not shown). Presence of CYSDV was confirmed by RT-PCR (data not shown)

In Fall 2007, frequencies of CYSDV symptoms in 'Top Mark', $\mathrm{F}_{1}, \mathrm{~F}_{2}$, and $\mathrm{BC}_{\mathrm{TM}}$ were nearly $100 \%$ at $49 \mathrm{dpp}$ (data not shown), but symptoms were not sufficiently developed to assess with the 1 to 4 scale. In contrast, PI 313970 was virtually asymptomatic $49 \mathrm{dpp}$, only one of 35 plants exhibited symptoms, and 42 of $79 \mathrm{BC}_{\mathrm{PI}}$ segregants exhibited symptoms. By 70 dpp, all plants of 'Top Mark', $F_{1}, F_{2}$, and $\mathrm{BC}_{\mathrm{TM}}$ were rated 4 for CYSDV symptom severity, and ratings on PI 313970 and $\mathrm{BC}_{\mathrm{PI}}$ ranged from 1 to 4 (Fig. 1-A).

The Fall 2008 test was similar to the 2007 test in that CYSDV symptoms were not sufficiently expressed $50 \mathrm{dpp}$ (data not shown), but by 63 dpp ranged across the 1 to 9 rating scale (Fig. 1B). In the Spring 2009 test, symptoms ranged across the 1 to 10 scale 82 dpp (Fig. 1C).

Nearly all plants in 2007 exhibited symptoms of $\mathrm{CuLCrV}$ at $49 \mathrm{dpp}$, but at $70 \mathrm{dpp}$, the frequency of plants that exhibited $\mathrm{CuLCrV}$ symptoms was lower: $67 \%$ and $28 \%$ of 'Top Mark' and PI 313970, respectively $\left(\mathrm{F}_{2}: 52 \%\right.$, $\mathrm{BC}_{\mathrm{TM}}: 54 \%, \mathrm{BC}_{\mathrm{PI}}: 9 \%$ ). Several cultivated cucurbit species exhibited recovery, most likely mediated by gene silencing and methylation. This was previously shown from particle bombardment-mediated infection by $\mathrm{CuLCrV}$ in which recovery was inversely correlated with virus titer and with melon and watermelon [Citrullus lanatus (Thumb.) 

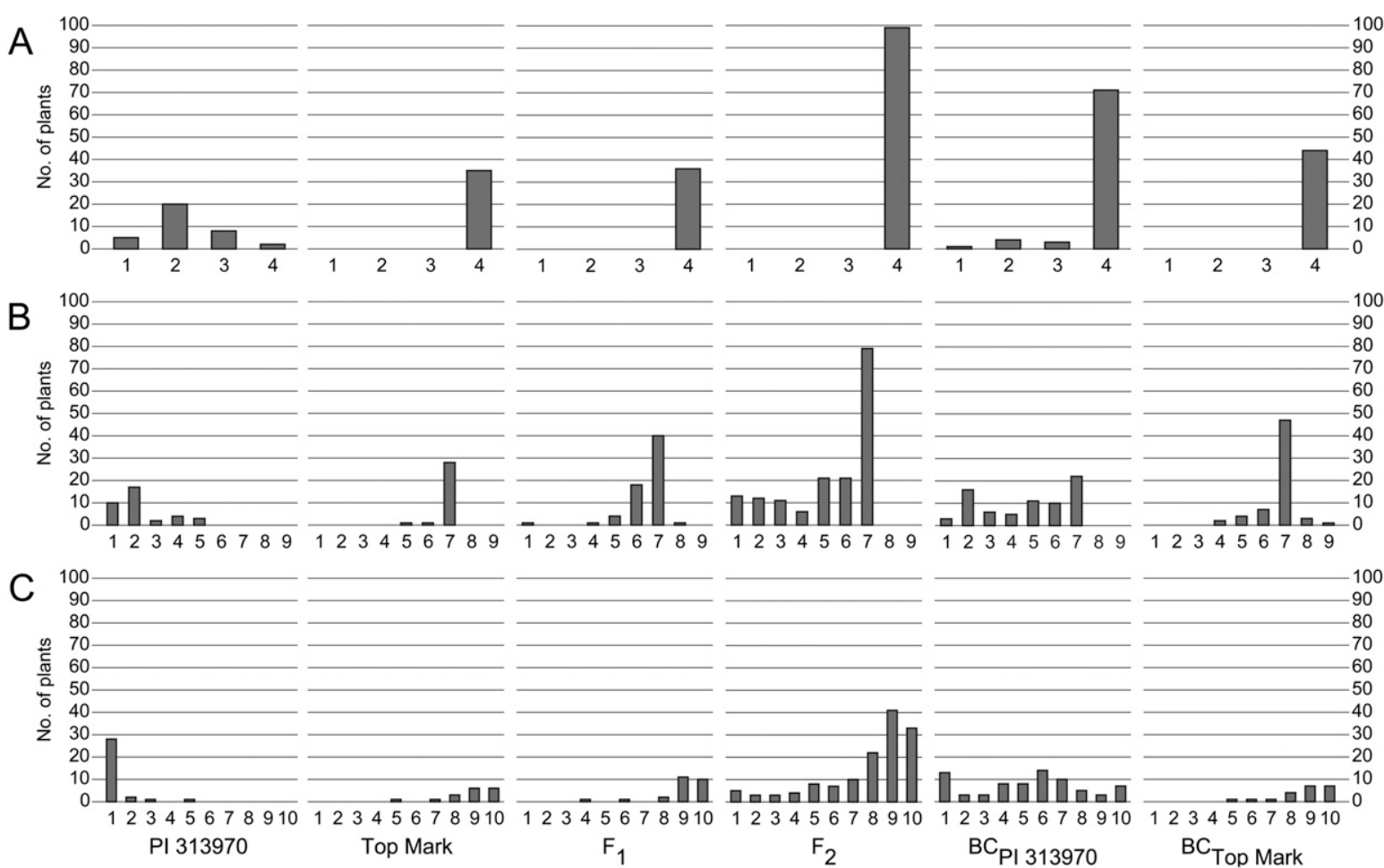

Fig. 1. Frequency distributions of Cucurbit yellow stunting disorder virus symptom severity ratings of CYSDV-resistant PI 313970, susceptible 'Top Mark', and their offspring in three seasons at Holtville, CA, during Fall 2007 (A), Fall 2008 at 63 dpp (B), and Spring 2009 (C) seasons using different rating scales as indicated by the X-axes. In 2007 (A), a 1 to 4 scale was used, where 1, asymptomatic; 2, mild; 3, crown; 4, extensive symptoms. In 2008 (B), a 1 to 9 scale was used, where 1, asymptomatic; 2 , possible symptoms; 3 , faint symptoms at crown; 4, obvious symptoms at crown; 5 , bright symptoms at crown; 6 , symptoms advancing toward tips; 7, symptoms further advanced toward crown; 8, some tips yellowed; 9 all tips symptomatic. In 2009 (C), a 1 ( $0 \%$ to $10 \%$ symptomatic) to $10(91 \%$ to $100 \%)$ scale was used to estimate the proportion of foliage that exhibited CYSDV symptoms.

Matsum \& Nakai] showing stronger recovery than zucchini (Cucurbita pepo L.) and pumpkin (Cucurbita maxima Duchesne) (Hagen et al., 2008). Some individual plants in five of 16 melon cultivars recovered from SPWF$\mathrm{B}$-mediated $\mathrm{CuLCrV}$ infection in greenhouse tests (McCreight et al., 2008). PI 313970, which also recovered from symptom expression in greenhouse tests, possesses a single recessive gene for partial resistance to $\mathrm{CuLCrV}$ (McCreight et al., 2008). Recovery has been reported in other host-Begomovirus associations (see Hagen et al., 2008, for a discussion) and is Begomovirus-specific (Carrillo-Tripp et al., 2007). In Fall 2008, all plants exhibited CuLCrV symptoms $49 \mathrm{dpp}$, but in contrast to 2007, the frequencies of plants exhibiting symptoms $70 \mathrm{dpp}$ remained high: $96 \%$ and $70 \%$ for 'Top Mark' and PI 313970, respectively, and ranged from $79 \%\left(\mathrm{BC}_{\mathrm{TM}}\right)$ to $87 \%$ $\left(\mathrm{F}_{2}\right)$ in their offspring. CuLCrV was not present in 2009.

Powdery mildew was not observed in 2007 or 2008 but was present in 2009. Powdery mildew resistance to race $\mathrm{S}$ in 2009 segregated in the $\mathrm{F}_{2}$ and $\mathrm{BC}_{\mathrm{PI}}$ generations as expected for a single recessive gene (McCreight and Coffey, 2011). There was no correlation between CYSDV and powdery mildew symptom severity ratings in either the $\mathrm{F}_{2}(r=-0.02)$ or the $\mathrm{BC}_{\mathrm{PI}}(r=0.004)$.

Analysis of variance of CYSDV symptom severity ratings was highly significant $(P<$ 0.0001 ) in each year. Mean symptom severity of PI 313970 and 'Top Mark' differed significantly $(P=0.05)$ in each season regardless of the rating scale used (Tables 1 and 2). PI 313970 exhibited significantly less CYSDV symptoms than the $\mathrm{F}_{1}, \mathrm{~F}_{2}$, and $\mathrm{BC}_{\mathrm{TM}}$ in all 3 years and the $\mathrm{BC}_{\mathrm{PI}}$ in 2007 and 2009. The $\mathrm{BC}_{\mathrm{TM}}$ was significantly more susceptible than the $\mathrm{BC}_{\mathrm{PI}}$ in 2007 and 2008 but not in 2009 (Table 2).

Frequency distributions of CYSDV symptom severity ratings in 2007 suggested PI 313970 is heterogeneous for resistance to CYSDV; its ratings ranged from 1 to 4 and overlapped 'Top Mark' (Fig. 1A). Selection for resistance to CYSDV in progeny from crosses with PI 313970 would be facilitated by initially selecting within PI 313970 for uniform reaction to CYSDV infection before crossing with susceptible parents. The $\mathrm{F}_{2}$ and $\mathrm{BC}_{\mathrm{TM}}$ were uniformly susceptible (Fig. 1), but the distribution of the $\mathrm{BC}_{\mathrm{PI}}$ was negatively skewed (Fig. 1A).

\section{Discussion}

These data confirmed the observation in 2006 that PI 313970 was resistant to CYSDV, although not immune (McCreight and Wintermantel, 2008). Susceptibility of the $F_{1}$ in each test suggested that resistance to CYSDV in PI 313970 is recessive (Table 2). This is in contrast to the report of dominant resistance to a Spanish isolate of CYSDV in TGR-1551 (López-Sesé and Gómez-Guillamón, 2000), although genetic control of resistance in TGR-1551 may be more complex or strain-specific (Sinclair, 2003). These data also indicate resistance to CYSDV is genetically distinct from resistance to Lettuce infectious yellows virus (LIYV), a crinivirus transmitted by SPWF biotype A that is controlled by a dominant gene in PI 313970 (McCreight, 2000).

Resistance to $\mathrm{CuLCrV}$ in PI 313970 was recessive in a greenhouse test in Salinas and field tests at DREC (McCreight et al., 2008). These field data from DREC suggest that resistances to CYSDV and CuLCrV traits are not allelic. All 35 plants of PI 313970 in 2007 exhibited symptoms of $\mathrm{CuLCrV}$ infection at $49 \mathrm{dpp}$; however, only 10 of them exhibited symptoms of CuLCrV infection $70 \mathrm{dpp}$ and these were distributed in all four CYSDV symptom severity classes. The $2008 \mathrm{CuLCrV}$ data (not shown) at both 49 and 70 dpp were similar to the data at $49 \mathrm{dpp}$ in 2007. This suggested that many plants exhibited recovery from $\mathrm{CuLCrV}$ infection in 2007, a trait common among some host plant-begomovirus interactions, including CuLCrV (CarrilloTripp et al., 2007; Hagen et al., 2008). Recovery did not occur in 2008, and CuLCrV was not present in 2009. Some individual plants in five of 16 melon cultivars recovered from $\mathrm{CuLCrV}$ infection in previous greenhouse tests (McCreight et al., 2008). PI 313970 , which also recovered from symptom expression in greenhouse tests, possesses a single recessive gene for partial resistance to $\mathrm{CuLCrV}$ (McCreight et al., 2008). Factors influencing recovery of plants from begomovirus infection 
Table 2. Mean severity ratings of symptoms incited by Cucurbit yellow stunting disorder virus in PI 313970, 'Top Mark', and their offspring in naturally infected field tests in 2007, 2008 and 2009 Holtville, CA.

\begin{tabular}{|c|c|c|c|c|c|c|c|}
\hline \multirow[b]{2}{*}{ Generation } & \multicolumn{2}{|c|}{$2007^{z}$} & \multicolumn{3}{|c|}{$2008^{y}$} & \multicolumn{2}{|c|}{$2009^{x}$} \\
\hline & $\mathrm{n}^{\mathrm{w}}$ & $70 \mathrm{dpp}^{\mathrm{v}}$ & $\mathrm{n}$ & $50 \mathrm{dpp}$ & $63 \mathrm{dpp}$ & $\mathrm{n}$ & $82 \mathrm{dpp}$ \\
\hline Top Mark (TM) & 35 & $4.0 \mathrm{a}^{\mathrm{u}}$ & 30 & $5.1 \mathrm{a}$ & $6.9 \mathrm{a}$ & 24 & $6.8 \mathrm{ab}$ \\
\hline PI 313970 (PI) & 35 & $2.2 \mathrm{c}$ & 36 & $2.6 \mathrm{c}$ & $2.2 \mathrm{~d}$ & 32 & $1.2 \mathrm{c}$ \\
\hline $\mathrm{F}_{1} \mathrm{TM} \times \mathrm{PI}$ & 36 & $4.0 \mathrm{a}$ & 32 & $4.5 \mathrm{a}$ & $6.5 \mathrm{a}$ & 29 & $7.8 \mathrm{ab}$ \\
\hline $\mathrm{F}_{1 \mathrm{PI} \times \mathrm{TM}}$ & - & - & 33 & $4.5 \mathrm{a}$ & $6.5 \mathrm{a}$ & - & - \\
\hline $\mathrm{F}_{2}$ & 99 & $4.0 \mathrm{a}$ & 163 & $3.5 \mathrm{~b}$ & $5.4 \mathrm{~b}$ & 152 & $7.8 \mathrm{a}$ \\
\hline $\mathrm{BC}_{\mathrm{TM}}$ & 44 & $4.0 \mathrm{a}$ & 64 & $4.8 \mathrm{a}$ & $6.7 \mathrm{a}$ & 22 & $8.3 \mathrm{ab}$ \\
\hline $\mathrm{BC}_{\mathrm{PI}}$ & 79 & $3.8 \mathrm{~b}$ & 73 & $3.5 \mathrm{~b}$ & $4.7 \mathrm{c}$ & 84 & $5.7 \mathrm{~b}$ \\
\hline
\end{tabular}

${ }^{\mathrm{z}} 1$ = asymptomatic; 2 = mild; $3=$ crown; 4 = extensive symptoms.

${ }^{\mathrm{y}} 1$ to 9 scale where 1 , asymptomatic; 2, possible symptoms; 3, faint symptoms at crown; 4, obvious symptoms at crown; 5 , bright symptoms at crown; 6 , symptoms advancing toward tips; 7 , symptoms further advanced toward crown; 8, some tips yellowed; 9 all tips symptomatic.

${ }^{\mathrm{x}} 1(0 \%$ to $10 \%)$ to $10(91 \%$ to $100 \%)$ scale estimated the proportion of foliage that exhibited symptoms. wumber of plants.

vDays post-planting.

${ }^{u}$ Within years, means followed by different letters are significantly $(P=0.05)$ different.

are only partially understood, and much remains to be determined. Recovery of plants infected by $\mathrm{CuLCrV}$ or other begomoviruses is likely mediated by methylation and gene silencing of virus gene expression, and plants exhibiting recovery generally have reduced virus titers in leaves exhibiting the recovery phenotype compared with non-recovered leaves (Hagen et al., 2008). Segregation of $\mathrm{CuLCrV}$ resistance did not fit the expected ratios in the $\mathrm{F}_{2}$ or $\mathrm{BC}_{\mathrm{PI}}$ generations in 2007 or 2008 experiments. This suggested a possible negative synergism between CYSDV and $\mathrm{CuLCrV}$ either at the phenotypic (symptom) or molecular level that either masks $\mathrm{CuLCrV}$ symptoms or more likely triggers the recovery phenotype. Clarification of the influence of coinfection by CYSDV on CuLCrV titer and host plant resistance to it in CYSDV-resistant plants will require more extensive study.

Resistance to CYSDV is likely independent of resistance to Cucurbit aphid borne yellowing virus (CABYV; Luteoviridae, Polerovirus) and Watermelon chlorotic stunt virus (WCSV; Geminiviridae, Begomovirus). CABYV was detected in some plants of PI 313970 , although this may be an indication of heterogeneity in PI 313970 (Dogimont et al., 1996). Two recessive genes controlled resistance to CABYV in PI 124112 (Dogimont et al., 1997), and presumably also in PI 313970, but the genetic relationship between resistances to CYSDV and CABYV in PI 313970 is unknown. PI 313970 is one of six melon accessions reported to have complete resistance to WCSV as evidenced by absence of symptoms and no detectable virus (Yousif et al., 2007). Inheritance of complete resistance to WCSV and its relationship to CYSDV resistance in PI 313970 are, likewise, unknown.

Overlap of the frequency distributions of PI 313970 and 'Top Mark' may have been attributable in part to an artifact of the 1 to 4 rating scale used to assess symptom severity in 2007. It was our observation that the 1 to 4 qualitative scale (Table 1) masked informative variation in symptom expression. In other words, phenotypic variation within Classes 2,3 , and 4 could be expressed on a more continuous scale. The 1 to 9 rating scale
(Table 1) used in 2008 separated the parents further, but their distribution again overlapped (Fig. 1B). Although their means were significantly different, the observed variability within PI 313970 still suggested potential for selection of more uniform reaction to CYSDV infection. The distributions of their offspring and segregating generations followed the same general pattern of the 2007 distributions with the exception that the $\mathrm{BC}_{\mathrm{PI}}$ was more evenly distributed (Fig. 1A-B).

The rating scale was changed in 2009 to a 1 to 10 scale to estimate percentage of symptomatic leaves per plant (Table 1). This scale simplified evaluation by ignoring symptom intensity, i.e., faint yellow vs. bright yellow, so that the focus was on the extent to which CYSDV symptoms were exhibited throughout the plant. This test was remarkable from three aspects. First, as a result of the lower SPWF-B feeding pressure in the spring season, there was no confounding effect of severe SPWF-B feeding damage per se that since 1990 has been characteristic of fall melons in the desert southwest United States, particularly in Imperial Valley (McCreight et al., 1995, 2010; Wisler et al., 1998); such numbers of SPWF have not been reported from any other production area. Second, CYSDV can reach $100 \%$ rates of infection at low-level SPWF-B infestation (McCreight et al., 2010). Third, CuLCrV was not observed in the spring test (Kuo et al., 2007), preventing any potentially confounding influence $\mathrm{CuLCrV}$ might have on CYSDV symptom expression.

CYSDV symptom severity frequency distributions of PI 313970 and 'Top Mark' in the 2009 test were further separated but still overlapped (Fig. 1C). The range of symptom expression in PI 313970, again, suggested potential genetic variation for selection of a uniform reaction to CYSDV. The range in 'Top Mark' may reflect differences in plant size at the time of infection, variation in SPWF-B distribution across the tests, and random variation in time of infection. Distributions of their offspring and segregating generations followed the same pattern observed in 2008 (Fig. 1B).
These data from three seasons suggest resistance to CYSDV in PI 313970 is controlled by a single recessive gene. The four different $\mathrm{F}_{1}$ and three different $\mathrm{BC}_{\mathrm{TM}}$ progenies included in the three tests were similar in their reactions to 'Top Mark', and the $\mathrm{F}_{2}$ and $\mathrm{BC}_{\mathrm{PI}}$ progenies segregated as expected for recessive resistance.

PI 313970 was, however, observed to be variable for resistance; a few plants in each test expressed distinct symptoms of CYSDV infection and its frequency distributions overlapped that of susceptible 'Top Mark'. The variation may be random or represent genetic variation to be selected on for uniform reaction to infection by CYSDV. Field selection in the fall season for uniform resistance is underway but is hampered by the decreased day and night temperatures and daylength that are unfavorable for controlled cross-, sib-, or self-pollination of selected plants. This problem is circumvented by transport of vegetative cuttings from selected plants for eventual pollination in a SPWFproof, secondary enclosure within a heated greenhouse through the winter at Salinas. Earlier planting of fall season melons in these areas could be a useful strategy to mitigate seasonal effects by permitting selection and cuttings in late September or early October when the success of pollination or rooting of cuttings is likely more efficient than in midNovember or early December. Selection in the spring season in Imperial Valley and Yuma is not as reliable as the fall season as a result of lower, more variable whitefly populations that may influence rate of infection. Although CYSDV incidence increased in spring crops in Imperial Valley from 2007 through 2009 (Wintermantel et al., 2010), the virus was not observed in either the Imperial Valley or Yuma production areas in Spring 2010.

Genetic resistance to CYSDV in PI 313970 does not confer immunity because the virus was detectable in all plants regardless of symptom expression using RT-PCR. Quantitative methods are being used for subsequent studies on replication and movement of CYSDV in PI 313970 and 'Top Mark'.

PI 313970 was resistant to SPWF-B in the Caribbean where populations of SPWF-B are lower than in the desert southwest United States (Boissot et al., 2003; McCreight et al., 1995, 2010). In Imperial Valley, it was apparent that the level of SPWF-B infestation (6-week means: 169 adults per leaf, 196 eggs/ $\mathrm{cm}^{2}, 128$ nymphs $/ \mathrm{cm}^{2}$ ) had a deleterious effect on plant condition of PI 313970 and 'Top Mark' in Fall 2008 compared with Spring 2009 when the SPWF-B population was much lower in numbers (6-week means: 49 adults per leaf, 16 eggs $/ \mathrm{cm}^{2}, 41$ nymphs/ $\mathrm{cm}^{2}$ ) (McCreight et al., 2010). Means and frequency distributions of CYSDV symptom ratings for PI 313970 and 'Top Mark' in Spring 2009 (low SPWF-B) were further skewed apart than in Fall 2008 (high SPWF-B) (Fig. 1B-C). High SPWF-B feeding pressure during the Fall 2008 season affected expression of resistance to CYSDV 
in PI 313970. Breeding for resistance to CYSDV should, therefore, be done under low SPWF-B feeding pressure either by implementation of aggressive SPWF-B control measures or planting when SPFW-B pressure will be low and CYSDV infection will be consistently uniform. This situation can be ensured in controlled greenhouse tests.

The genetic relationship of the resistances to CYSDV in PI 313970 and TGR-1551 has not been reported. TGR-1551 expressed highlevel resistance in Fall 2007 to CYSDV in a naturally infected field test in Imperial Valley, CA (McCreight and Wintermantel, 2008). Resistance in TGR-1551 was initially reported to be dominant (López-Sesé and Gómez-Guillamón, 2000), but data from Texas suggest it may be codominant and complex (Sinclair, 2003). Alternatively, CYSDV resistance in TGR-1551 may be affected by environmental variation or be strain-specific, although there is limited genetic variability among most CYSDV isolates with the exception of isolates from Saudi Arabia (Rubio et al., 2001). The intriguing question is whether the combination of these distinctly different sources of resistance to CYSDV can provide a higher and more uniform level of resistance than either alone.

PI 313970 is a source of host plant resistance to an increasing number of disease and insect pests. This research adds resistance to CYSDV to a list of resistance of four other viruses: CABYV (Dogimont et al., 1996), CuLCrV (McCreight et al., 2007), LIYV (McCreight, 2000), and WCSV (Yousif et al., 2007). PI 313970 is also valuable for resistance to several insect pests of melon. It is resistant to one genotype and susceptible to a second genotype of the melon aphid, Aphis gossypii Glover (Boissot et al., 2008). It is resistant to the agromyzid leafminer, Liriomyza sativae Blanchard (munda Frick), expressed as mean number of mines per leaf and as percent mortality of larvae (Kennedy et al., 1978). Resistance in 90625 (PI 313970) to melonworm, Diaphania hyalinata L., was likely the result of antixenosis (Boissot et al., 2000). Of immediate interest is its reported resistance to SPWF-B (Boissot et al., 2003), although this can be overcome with heavy whitefly infestation. PI 313970 is a source of salt tolerance in melon (Shannon et al., 1984). PI 313970 is, furthermore, a source of unique, dominant, codominant, and recessive genes for resistance to $P$. xanthii races 1, 2, 2U.S., 3, 3.5, 4.5, 5, and S (McCreight, 2003; McCreight and Coffey, 2011; Pitrat and Besombes, 2008; Shishkoff, 2000).

The two sources of high-level genetic resistance to southwest U.S. strains of CYSDV known in melon are from geographically different areas: TGR-1551 from Zimbabwe and PI 313970 from India. Their vegetative characters are distinctly unique. Under Imperial Valley conditions, PI 313970 has exceptionally large, vigorous plants and the foliage is yellow-green in color. In contrast, TGR-1551 plants are smaller than commercial cultivars and have gray-green foliage. Both accessions produce fruit smaller than western U.S shipping-type muskmelons that are oval or elliptic with some tendency to pyriform shape, neither aromatic nor sweet, and used as fresh or cooked vegetables. Introgression of resistance to CYSDV from these exotic melons to large, aromatic, sweet melons is a formidable challenge and is confounded by the uncertainty of the genetic control of resistance and the possibility of environmental variation or strain-specific resistance to CYSDV in TGR-1551. Resistance to CYSDV in PI 313970 appears to be effective, but selection pressure will be have to be high and alternate inbreeding with backcrossing required to make effective progress with a recessive trait in a conventional selection scheme (Scully and Federer, 1993). Moreover, PI 313970 possesses many other host plant resistance genes that enable development of a multiple disease- and insect-resistant and heat and salt-tolerant melon (Dhillon et al., 2011).

\section{Literature Cited}

Abou-Jawdah, Y., H. Sobh, A. Fayad, H. Lecoq, B. Delécolle, and J. Trad-Ferré. 2000. Cucurbit yellow stunting disorder virus - A new threat to cucurbits in Lebanon. J. Plant Pathol. 82:5560.

Berdiales, B., J.J. Bernal, E. Saez, B. Woudt, F. Beitia, and E. Rodriguez-Cerezo. 1999. Occurrence of Cucurbit yellow stunting disorder virus (CYSDV) and Beet pseudo-yellows virus in cucurbit crops in Spain and transmission of CYSDV by two biotypes of Bemisia tabaci. Eur. J. Plant Pathol. 105:211-215.

Birdsall, S.L. 1991. 1990 Agricultural crop \& livestock report, Imperial County, CA. 30 Nov. 2011. <http://imperialcounty.net/ag/>.

Birdsall, S.L. 2007. 2006 Agricultural crop \& livestock report, Imperial County, CA. 30 Nov. 2011. <http://imperialcounty.net/ag/>.

Boissot, N., D. Lafortune, C. Pavis, and N. Sauvion. 2003. Field resistance to Bemisia tabaci in Cucumis melo. HortScience 38:77-80.

Boissot, N., P. Mistral, V. Chareyron, C. Dogimont, and M. Pitrat. 2008. A new view on aphid resistance in melon: The role of Aphis gossypii variability 163-171. In: Pitrat, M. (ed.). Cucurbitaceae 2008, IXth EUCARPIA Meeting on Genetics and Breeding of Cucurbitaceae. INRA, Avignon, France.

Boissot, N., C. Pavis, R. Guillaume, D. Lafortune, and N. Sauvion. 2000. Insect resistance in Cucumis melo accession 90625. Proceedings of 7th EUCARPIA meeting on Cucurbit Genetics and Breeding. Acta Hort. 510:297-304.

Brown, J.K., J.C. Guerreo, M. Matheron, M. Olsen, and A.M. Idris. 2007. Widespread outbreak of Cucurbit yellow stunting disorder virus (CYSDV) in the Sonoran plateau region of the Western U.S. and Pacific coast of Mexico. Plant Dis. 91:773.

Carrillo-Tripp, J., E. Lozoya-Gloria, and R.F. Rivera-Bustamante. 2007. Symptom remission and specific resistance of pepper plants after infection by Pepper golden mosaic virus. Phytopathology 97:51-59.

Desbiez, C., H. Lecoq, S. Aboulama, and M. Peterschmitt. 2000. First report of Cucurbit yellow stunting disorder virus in Morocco. Plant Dis 84:596.

Desbiez, C., H. Lecoq, M. Girard, A.C. Cotillon, and L. Schoen. 2003. First report of Cucurbit yellow stunting disorder virus in commercial cucumber greenhouses in France. Plant Dis 87:600.

Dhillon, N.P.S., A.J. Monforte, M. Pitrat, S. Pandey, P.K. Singh, K.R. Reitsma, J. Garcia-Mas, A. Sharma, and J.D. McCreight. 2011. Melon landraces of India: Contributions and importance 85-150. In: Janick, J. (ed.). Plant breeding rev. John Wiley \& Sons, Inc., Hoboken, NJ.

Dogimont, C., A. Bussemakers, J. Martin, S. Slama, H. Lecoq, and M. Pitrat. 1997. Two complementary recessive genes conferring resistance to Cucurbit aphid borne yellows luteovirus in an Indian melon line (Cucumis melo L.). Euphytica 96:391-395.

Dogimont, C., S. Slama, J. Martin, H. Lecoq, and M. Pitrat. 1996. Sources of resistance to cucurbit aphid-borne yellows luteovirus in a melon germ plasm collection. Plant Dis. 80:13791382.

Duffus, J.E. 1965. Beet pseudo-yellows virus, transmitted by the greenhouse whitefly (Trialeurodes vaporariorum). Phytopathology 55: 450-453.

Duffus, J.E. 1995. Whitefly transmitted yellowing viruses of the Cucurbitaceae. Cucurbitaceae '94: Evaluation and Enhancement of Cucurbit Germplasm, 1-4 Nov. 1994, South Padre Island, TX, Edinburg, TX. p. 12-16.

Eid, S., Y. Abou-Jawdah, C. El-Mohtar, H. Sobh, and M. Havey. 2006. Tolerance in cucumber to Cucurbit yellow stunting disorder virus. Plant Dis. 90:645-649.

Elena, K., A.S. Alivizatos, and C. Varveri. 2008. New plant pathogens reported in Greece, 1990 2007. Hellenic Plant Protection J. 1:1-25.

FAO. 2011. FAOSTAT. 29 Oct. 2011. <http://faostat. fao.org/>.

Guzman, P., M.R. Sudarshana, Y.S. Seo, M.R. Rojas, E. Natwick, T. Turini, K. Mayberry, and R.L. Gilbertson. 2000. A new bipartite geminivirus (Begomovirus) causing leaf curl and crumpling in cucurbits in the Imperial Valley of California. Plant Dis. 84:488.

Hagen, C., M.R. Rojas, T. Kon, and R.L. Gilbertson. 2008. Recovery from Cucurbit leaf crumple virus (family Geminiviridae, genus Begomovi$r u s$ ) infection is an adaptive antiviral response associated with changes in viral small RNAs. Phytopathology 98:1029-1037.

Hassan, A.A. and J.E. Duffus. 1990. Observations and investigations on the yellow and stunting disorder of cucurbits in the United Arab EmiratesA review. Emirates J. Agr. Sci. 2:1-16.

Henneberry, T.J., N.C. Toscano, and S.J. Castle. 1998. Bemisia spp. (Homoptera: Aleyrodidae) in the United States history, pest status, and management. Recent Res. Develop. Entomol. 2:151-161.

Jones, D.R. 2003. Plant viruses transmitted by whiteflies. Eur. J. Plant Pathol. 109:195-219.

Kao, J., L. Jia, T. Tian, L. Rubio, and B.W. Falk. 2000. First report of Cucurbit yellow stunting disorder virus (genus Crinivirus) in North America. Plant Dis. 84:101.

Kennedy, G.G., G.W. Bohn, A.K. Stoner, and R.E. Webb. 1978. Leafminer resistance in muskmelon. J. Amer. Soc. Hort. Sci. 103:571-574.

Keshavarz, T. and K. Izadpanah. 2004. Report of Cucurbit yellow stunting disorder virus (Genus crinivirus) in Iran, p. 264-265. Proc. of 16th Iranian Plant Prot. Congr., Tabriz, 2004, Faculty of Agriculture, Tabriz, Iran.

Kuo, Y.-W., M.R. Rojas, R.L. Gilbertson, and W.M. Wintermantel. 2007. First report of Cucurbit yellow stunting disorder virus in California and Arizona, in association with Cucurbit leaf crumple virus and Squash leaf curl virus. Plant Dis. 91:330. 
Liu, L.Z., Y.Y. Chen, and W.M. Zhu. 2010. First report of Cucurbit yellow stunting disorder virus on melon in China. Plant Dis. 94:485.

López-Sesé, A.I. and M.L. Gómez-Guillamón. 2000. Resistance to Cucurbit yellowing stunting disorder virus (CYSDV) in Cucumis melo L. HortScience 35:110-113.

Louro, D., M. Vicente, A.M. Vaira, G.P. Accotto, and G. Nolasco. 2000. Cucurbit yellow stunting disorder virus (Genus Crinivirus) associated with the yellowing disease of cucurbit crops in Portugal. Plant Dis. 84:1156.

McCreight, J.D. 2000. Inheritance of resistance to lettuce infectious yellows virus in melon. HortScience 35:1118-1120.

McCreight, J.D. 2003. Genes for resistance to powdery mildew races 1 and 2U.S. in melon PI 313970. HortScience 38:591-594.

McCreight, J.D. 2006. Melon-powdery mildew interactions reveal variation in melon cultigens and Podosphaera xanthii races 1 and 2. J. Amer. Soc. Hort. Sci. 131:59-65.

McCreight, J.D. and M.D. Coffey. 2011. Inheritance of resistance in melon PI 313970 to cucurbit powdery mildew incited by Podosphaera xanthii race S. HortScience 46:838840 .

McCreight, J.D., G.W. Elmstrom, A.M. Simmons, and D.W. Wolff. 1995. Silverleaf whitefly on melons in California, Florida, South Carolina and Texas, p. 210-213. In: Lester, G.E. and J.R. Dunlap (eds.). Proc. Cucurbitaceae '94: Evaluation and Enhancement of Cucurbit Germplasm. South Padre Island, TX, 1-4 Nov. 1994. Gateway Printing and Office Supply, Edinburg, TX.

McCreight, J.D., H.-Y. Liu, and T.A. Turini. 2007. Genetic resistance to Cucurbit leaf crumple virus in melon. HortScience 42:1-5.

McCreight, J.D., H.-Y. Liu, and T.A. Turini. 2008. Genetic resistance to Cucurbit leaf crumple virus in melon. HortScience 43:122-126.

McCreight, J.D., H. Nerson, and R. Grumet. 1992. Melon (Cucumis melo L.). In: Kalloo, G. and B.O. Bergh (eds.). Improvement of vegetable crops. Pergamon Press, Oxford, UK.

McCreight, J.D., H. Nerson, and R. Grumet. 1993. Melon, p. 267-294. In: Kalloo, G. and B.O. Bergh (eds.). Genetic improvement of vegetable crops. Pergamon Press, New York, NY.

McCreight, J.D. and W.M. Wintermantel. 2008. Potential new sources of genetic resistance in melon to Cucurbit yellow stunting disorder virus, p. 173-179. In: Pitrat, M. (ed.). Cucurbitaceae 2008, Proc. of the IXth EUCARPIA meeting on genetics and breeding of Cucurbitaceae, 21-24 May 2008. INRA, Avignon, France.

McCreight, J.D., W.M. Wintermantel, E.T. Natwick, and J.C. Palumbo. 2010. Integrated pest management for melon production in the desert Southwest United States. Cucurbitaceae 2010 Proc., 14-18 Nov. 2010, Charleston, SC. p. 80 83.

Papayiannis, L.C., N. Ioannou, I.N. Boubourakas, C.I. Dovas, N.I. Katis, and B.W. Falk. 2005. Incidence of viruses infecting cucurbits in Cyprus. J. Phytopathol. 153:530-535.

Pitrat, M. and D. Besombes. 2008. Inheritance of Podosphaera xanthii resistance in melon line '90625', p. 135-142. In: Pitrat, M. (ed.) Cucurbitaceae 2008, IXth EUCARPIA Meeting on Genetics and Breeding of Cucurbitaceae. INRA, Avignon, France.

Polston, J.E., L.L. Hladky, F. Akad, and W.M. Wintermantel. 2008. First report of Cucurbit yellow stunting disorder virus in cucurbits in Florida. Plant Dis. 92:1251.

Robinson, R.W. and D.S. Decker-Walters. 1997. Cucurbits. CAB International, New York, NY.

Rubio, L., Y. Abou-Jawdah, H.-X. Lin, and B.W. Falk. 2001. Geographically distant isolates of the crinivirus Cucurbit yellow stunting disorder virus show very low genetic diversity in the coat protein gene. J. Gen. Virol. 82:929-933.

Rubio, L., J. Soong, J. Kao, and B.W. Falk. 1999. Geographic distribution and molecular variation of isolates of three whitefly-borne closteroviruses of cucurbits: Lettuce infectious yellows virus, Cucurbit yellow stunting disorder virus, and Beet pseudo-yellows virus. Phytopathology 89:707-711.

Scully, B.T. and W.T. Federer. 1993. Application of genetic theory in breeding for multiple virus resistance, p. 167-195. In: Kyle, M.M. (ed.). Resistance to viral diseases of vegetables. Timber Press, Portland, OR.

Sedlářová, M., A. Lebeda, P. Mikšíková, M Duchoslav, B. Sedláková, and J.D. McCreight. 2009. Histological aspects of Cucumis melo PI 313970 resistance to Podosphaera xanthii and Golovinomyces cichoracearum. J. Plant Dis. Prot. 116:169-176.

Shannon, M.C., G.W. Bohn, and J.D. McCreight. 1984. Salt tolerance among muskmelon geno- types during seed emergence and seedling growth. HortScience 19:828-830.

Shishkoff, N. 2000. The name of the cucurbit powdery mildew: Podosphaera (sect. Sphaerotheca) xanthii (Castag.) U. Braun \& N. Shish. comb. nov. Phytopathology 90:S133.

Sinclair, J.W. 2003. Screening for resistance to cucurbit yellow stunting disorder virus, gummy stem blight, and monosporascus root rot and detection of RAPD markers associated with QTL for soluble solids, sugars, and vitamin C in melon (Cucumis melo L.). PhD diss., Dept. Hort. Sci., Texas A\&M Univ., College Station, TX.

Tzanetakis, I.E., W.M. Wintermantel, and R.R. Martin. 2003. First report of Beet pseudo yellows virus in strawberry in the United States: A second Crinivirus able to cause pallidosis disease. Plant Dis. 87:1398.

USDA-NASS. 2009. Arizona Annual Crops Summary. 30 Nov. 2011. <http://www.nass.usda. gov/Statistics_by_State/Arizona/Publications/ Annual_Crops_Summary/index.asp $>$.

USDA-NASS. 2010. Vegetables 2009 summary.

Wintermantel, W.M. 2004. Pumpkin (Cucurbito maxima and $C$. pepo), a new host of Beet pseudo yellows virus in California. Plant Dis. 88:82.

Wintermantel, W.M., R.L. Gilbertson, E.T. Natwick, and J.K. Brown. 2010. Emergence and establishment of Cucurbit yellow stunting disorder virus in California and poses a threat to desert melon production. Phytopathology 100:S138 (abstr.).

Wintermantel, W.M., L.L. Hladky, A.A. Cortez, and E.T. Natwick. 2009. A new expanded host range of Cucurbit yellow stunting disorder virus includes three agricultural crops. Plant Dis. 93:685-690.

Wisler, G.C., J.E. Duffus, H.Y. Liu, and R.H. Li. 1998. Ecology and epidemiology of whitefly transmitted closteroviruses. Plant Dis. 82:270 280.

Yakoubi, S., C. Desbiez, H. Fakhfakh, C. WipfScheibel, M. Marrakchi, and H. Lecoq. 2007. Occurrence of Cucurbit yellow stunting disorder virus and Cucumber vein yellowing virus in Tunisia. J. Plant Pathol. 89:417-420.

Yousif, M.T., A. Kheyr-Pour, B. Gronenborn, M. Pitrat, and C. Dogimont. 2007. Sources of resistance to Watermelon chlorotic stunt virus in melon. Plant Breed. 126:422-427. 